\title{
The Use of Pocket Electronic Dictionaries by Thai University Students
}

Atipat Boonmoh, Department of Language Studies, School of Liberal Arts, King Mongkut's University of Technology Thonburi, Bangmod, Thailand

(atipat.boo@kmutt.ac.th /atipat_b@yahoo.com)

\begin{abstract}
This article reports on a small-scale study of Thai-speaking learners using pocket electronic dictionaries (PEDs) to read an English news article. It investigates how the subjects use their PEDs for reading comprehension. Thirty-nine undergraduate students completed a questionnaire survey. Of these, four were chosen to participate in the experiment. Observations and interviews were utilized to ascertain how the subjects used their PEDs. The findings showed superficial and partial reading of the dictionary entries. It also revealed several factors that may hinder dictionary look-up success. On the basis of this research, guidelines for buying PEDs and for teaching PED skills are proposed.
\end{abstract}

Keywords: DICTIONARY USE, POCKET ELECTRONIC DICTIONARY, DICTIONARY CONSULTATION, MONOLINGUAL DICTIONARY, BILINGUAL DICTIONARY

Opsomming: Die gebruik van sak- elektroniese woordeboeke deur Thaise universiteitstudente. Hierdie artikel doen verslag van 'n kleinskaalse studie van Thaisprekende aanleerders wat sak- elektroniese woordeboeke (SEW's) gebruik om 'n Engelse nuusartikel te lees. Dit ondersoek hoe die proefpersone hul SAW's gebruik vir leesbegrip. Nege-en-dertig voorgraadse studente het ' $n$ vraelysopname voltooi. Uit hulle is vier gekies om aan die eksperiment deel te neem. Waarnemings en onderhoude is aangewend om te bepaal hoe die proefpersone hul SEW's gebruik het. Die bevindings het oppervlakkige en gedeeltelike lees van die woordeboekinskrywings getoon. Dit het ook verskeie faktore uitgewys wat woordeboekopsoeksukses mag belemmer. Op grond van hierdie navorsing word riglyne vir die koop van SEW's en vir die onderrig van SEWvaardighede voorgestel.

Sleutelwoorde: WOORDEBOEKGEBRUIK, SAK- ELEKTRONIESE WOORDEBOEK, WOORDEBOEKRAADPLEGING, EENTALIGE WOORDEBOEK, TWEETALIGE WOORDEBOEK

\section{Introduction}

Educators usually recognize the reliability of the major printed English learner's dictionaries, but they are less likely to appreciate pocket electronic dictionaries (PEDs) since PEDs are normally developed and advertised in terms of their technology rather than their lexicographical features. PEDs are, how- 
ever, common in South East Asian classrooms (Boonmoh and Nesi 2008, Deng 2005, Midlane 2005), their use being greatest in 'countries where PEDs are more cheaply and easily available ... and cultures in which microelectronic devices are extremely popular and fashionable' (Midlane 2005).

At King Mongkut's University of Technology Thonburi (KMUTT), Thailand, teachers have encouraged undergraduates to buy either the Longman Active Study Dictionary (LASD), or the Cambridge Learner's Dictionary (CLD), which is used as a key text in dictionary training skills courses. However, students seem to prefer to use PEDs when they are left to their own devices. A survey by Boonmoh and Nesi (2008) found that out of 1211 students, 1149 reported that they own at least one dictionary $(95 \%)$. Of these, $938(82 \%)$ own a monolingual dictionary in book form (presumably the LASD), $521(45 \%)$ own a bilingual dictionary in book form, and $456(40 \%)$ own PEDs. The survey indicated a mismatch, however, between the number of students who stated that they own monolingual print dictionaries (1149) and the number who stated that they normally use them (46 for reading, and 103 for writing). The number of subjects who said that they own PEDs (456), on the other hand, was found to correspond quite well with the number of subjects who said that they normally use them (435 for reading, and 412 for writing). The students were required by their tutors to purchase the monolingual dictionary (the LASD), but PED use seems to have been the students' own choice.

\subsection{Research in electronic dictionary use}

Electronic dictionary use is an under-researched area (Jopling 2003, Tono 2000); and the few studies that look closely at what happens when electronic dictionaries are consulted mainly concern the use of learner's dictionaries on CD-ROM (e.g. Jopling 2003, Nesi and Haill 2002, Winkler 2001). Most prior research into PED use has been confined to quantitative ownership surveys (e.g. Deng 2005, Taylor and Chan 1994) and qualitative investigations into teacher and student attitudes and beliefs (e.g. Boonmoh and Nesi 2008, Sobkowiak 2002). A few simple experiments have been conducted, such as a look-up 'race' between PED and print dictionary users (Weschler and Pitts 2000), but there have been no close analyses of exactly what happens when PED users look up words. The 'Green tea' experiment is an attempt to fill in this research gap.

\subsection{Research methods of researching PED use}

Questionnaires and interviews have been among the most frequently used instruments for PED research (Boonmoh and Nesi 2008, Deng 2005, Sobkowiak 2002, Koren 1997, Tang 1997, and Taylor and Chan 1994) since they can be used as a way of obtaining results from a great number or respondents. They can be useful for identifying general trends which might then be examined more 
closely in smaller, more empirical studies. A questionnaire alone, however, cannot reveal 'exactly what ... students are doing with their dictionaries, what they expect from them, and how easily they are satisfied during the process of consultation' (Atkins and Varantola 1998: 115). For this reason, it seems a good idea to triangulate questionnaire data with more qualitative data obtained by other means.

Observation is an obvious means of collecting data in educational settings. Observing PED use in a natural setting is almost impossible because PED consultation is a private activity, and one which learners are often inclined to be secretive about (Nesi and Haill 2002). Video recording users, a method employed by Jopling (2003) when investigating the use of CD-ROM dictionaries, may not be a practical means of researching PED use since PED users may often hunch over their PEDs when consulting them, and block the view of the video camera. Although 'spy' software has some potential as a means of observing online dictionary use (through keystroke logging and screenshots), it cannot be loaded into the standard PED. Although PED consultation is a private activity, observing its use may provide us with a better understanding of how students really use their PEDs.

\section{Purposes of the study}

The purposes of this study are to find out

- what type of dictionary students possess, use, and want to buy,

- how students use their PEDs to read an English news article, and

- how successful their PED consultations are.

\section{Methodology}

\subsection{Subjects}

The subjects of this study were 39 first-year undergraduate students who enrolled in a foundation English course (LNG 102 Fundamental English II) in the second semester of the academic year 2009 (November 2009-February 2010) at King Mongkut's University of Technology. They were from three departments: Computer Engineering, Mathematics and Multimedia. These subjects were chosen because they enrolled in the foundation English course which was taught by the researcher. Of 39 subjects, 4 were selected to take part in the experiment. These 4 subjects were chosen because they had claimed to possess and use pocket electronic dictionaries, and had indicated their willingness to participate in the experiment. 


\subsection{Research instruments}

A questionnaire, interviews, and observations were employed in this study. Initially, a questionnaire entitled 'Dictionary Use of Thai University Students' was completed by 39 subjects. The questionnaire consisted of 3 questions whose aim was to find out students' dictionary ownership, preference for dictionary use, and preference for dictionary purchase. Based on the findings of the questionnaire, only those who reported that they possess PEDs (10 subjects) were asked to participate in the study. Only 4 subjects expressed an interest in the study. Therefore each of them, in an individual session, was asked to complete a reading task. Subjects were asked to read a news article and orally reported what the article was about. This article was taken and adapted from a BBC website http://news.bbc.co.uk/2/hi/health/8453628.stm entitled 'Green tea "may block lung cancer"' which discusses that drinking green tea may avoid the risk of lung cancer.

This text had been piloted with a comparable group of volunteers, and had proved to be appropriate in terms of topic, difficulty level and length.

Subjects were asked to read the article in individual sessions, in the presence of the researcher who also observed every word looked up and completed an observation check sheet. The check sheets were used to help him record the words and meanings the subjects looked up, and were also used as notes to ask some specific questions during the retrospective interviews conducted with each subject at the end of the session.

\section{Green tea 'may block lung cancer'}

Drinking green tea may offer some protection against lung cancer, say experts who studied the disease at a medical university in Taiwan.

The latest work in more than 500 people adds to growing evidence suggesting the beverage has anti-cancer powers. In the study, smokers and non-smokers who drank at least a cup a day cut their lung cancer risk significantly, a US cancer research conference heard. The protection was greatest for people carrying certain genes. But cancer experts said the findings did not change the fact that smoking is bad for health.

Green tea is made from the dried leaves of the Asian plant Camellia sinesis and is drunk widely across Asia. The rates of many cancers are much lower in Asia than other parts of the world, which has led some to link the two. Laboratory studies have shown that extracts from green tea, called polyphenols, can stop cancer cells from growing. But results from human studies have been mixed. Some have shown a protective effect while others have failed to find any evidence of protection.

In July 2009, the Oxford-based research group Cochrane published a review of 51 studies on green tea and cancer which included over 1.5 million people. They concluded that while green tea is safe to drink in moderation, the research so far is conflicting about whether or not it can prevent certain cancers. (229 words) 


\subsection{Data analysis}

Findings were derived from consideration of three data sources: the questionnaire, observation notes, and interviews. The data was analyzed only when the subjects consulted their PEDs to comprehend the English passage. The number of words looked up, and the number of successful and unsuccessful look-ups were noted. The data from the interviews, and the observation check sheets were analyzed with reference to the following questions:

- How did the subjects write their summaries?

- What words did they look up?

- Did they search for words in the appropriate word class?

- Did they find the words they were looking for?

\section{4. $\quad$ Result}

\subsection{Student's use of dictionaries}

Table 1: Dictionary Use of Thai University Students

\begin{tabular}{|l|l|}
\hline Gender & 17 Male \\
& 22 Female \\
\hline \multirow{4}{*}{ Department } & 7 Mathematics \\
& 26 Engineering \\
& 6 Multimedia \\
\hline & 32 Monolingual dictionary in book form \\
& 35 Bilingual dictionary in book form \\
& 10 Pocket electronic dictionary \\
& 9 Monolingual dictionary in CD form \\
\hline & 4 Monolingual dictionary in book form \\
2. Dictionaries you normally use & 30 Bilingual dictionary in book form \\
& 9 Pocket electronic dictionary \\
& 4 Monolingual dictionary in CD form \\
\hline 3. Type of dictionaries you & 22 Pocket electronic dictionary \\
plan/would like to buy & 13 Bilingual dictionary in book form \\
& 4 Monolingual dictionary in book form \\
\hline
\end{tabular}

It can be seen from Table 1 that of 39 respondents, 35 (90\%) owned a bilingual dictionary in book form, 32 (82\%) owned a monolingual dictionary in book form which was a recommended purchase by the School (78\% wrote 'Cambridge', probably referring to CLD), and 10 (26\%) owned PEDs. The CLD on CD-ROMs are 'bundled' with the printed copies of CLD on sale at KMUTT. 
However, only 9 respondents claimed ownership of a monolingual dictionary on CD-ROM. This may suggest that many respondents had not explored the inside of their CLD copies.

For the second question, there was a 90\% drop in the number of respondents who used a monolingual dictionary. Although 32 respondents claimed to own a monolingual dictionary, only 4 respondents $(10 \%)$ reported that they normally use it. This may be taken to imply that the ownership of a certain type of dictionary does not equate to its use. However, the number of respondents who reported owning a bilingual dictionary in book form and a PED seem to correspond with the number of respondents who reported using it.

The last question enquired about the respondents' preferences when buying a new dictionary. More than half of the participants, $56 \%$ (22 out of 39), reported that they would like to buy PEDs, 13 respondents wanted to buy a bilingual dictionary in book form, and only 4 students (12.5\%) wanted to buy a monolingual dictionary in book form. None stated that they would want to buy dictionaries on CD-ROM.

The findings from this survey provided a general picture of how participants used their dictionaries. The findings inform us about the dictionaries the participants owned, which dictionaries they preferred to use or normally used, and which dictionaries they would like to buy in future.

\subsection{Students' reading behaviours and look-up analysis}

The ways these 4 subjects read the article were obvious. All of them started looking up unknown words from the beginning. None of them read a second time. Subject A, B and C read the article sentence by sentence and looked up unknown words while Subject D read the article word by word and tried to understand the word before moving to another word.

A PED normally contains at least three dictionaries, i.e. a Thai-English, an English-Thai, and an English-English dictionary. The sources of the three dictionaries differ among PED brands (e.g. CyberDict vs. TalkingDict) and PED models (e.g. CyberDict 3 vs. CyberDict 4). In this study, Subject A, B, and C used PEDs by CyberDict and Subject D used PEDs by TalkingDict. It was found that all 4 subjects consulted only the English-Thai PED dictionary. This was probably because the English-Thai dictionary was set up as the default when a PED is turned on. The interview also suggested that the subjects were not familiar with the English-English dictionary and they thought that looking up words from an English-English dictionary was time-consuming. Some stated that they could not understand the English definitions and they had to use the EnglishThai dictionary in order to understand some English words in the definitions.

As can be seen in Table 2, the numbers of dictionary look-ups per subject ranged from 22 (Subject C) to 40 (Subject D). Subject D looked up one in every five words (40 look-ups out of 229 words) in the English news article. This might have reflected the fact that Subject D tackled reading the article word for word. 
Table 2: Subjects' look-up analysis

\begin{tabular}{|c|c|c|c|c|}
\hline Subject & $\begin{array}{c}\text { Number of } \\
\text { look-ups }\end{array}$ & $\begin{array}{c}\text { Words placed } \\
\text { in the wrong } \\
\text { order }\end{array}$ & $\begin{array}{c}\text { Inappropriate } \\
\text { words } \\
\text { searched }\end{array}$ & $\begin{array}{c}\text { Unsuccessful } \\
\text { look-ups }\end{array}$ \\
\hline $\begin{array}{l}\text { A } \\
(\text { CyberDict })\end{array}$ & 28 & research & $\begin{array}{l}\text { leaves, } \\
\text { suggesting, } \\
\text { conflicting, } \\
\text { published }\end{array}$ & - \\
\hline $\begin{array}{l}\text { B } \\
(\text { CyberDict })\end{array}$ & 30 & $\begin{array}{l}\text { research, may, } \\
\text { rate }\end{array}$ & $\begin{array}{l}\text { leaves, } \\
\text { expects, } \\
\text { extracts, } \\
\text { published, } \\
\text { adds, } \\
\text { conflicting }\end{array}$ & - \\
\hline $\begin{array}{l}\text { C } \\
\text { (CyberDict) }\end{array}$ & 22 & $\begin{array}{l}\text { research, } \\
\text { review, }\end{array}$ & $\begin{array}{l}\text { extracts, } \\
\text { published, } \\
\text { suggesting }\end{array}$ & - \\
\hline $\begin{array}{l}\text { D } \\
\text { (TalkingDict) }\end{array}$ & 40 & $\begin{array}{l}\text { link, research, } \\
\text { rate, may, } \\
\text { review }\end{array}$ & $\begin{array}{l}\text { leaves, } \\
\text { smokers, } \\
\text { experts, } \\
\text { extracts, adds, } \\
\text { suggesting, } \\
\text { conflicting, } \\
\text { growing, } \\
\text { published, } \\
\text { included }\end{array}$ & $\begin{array}{l}\text { smokers, } \\
\text { experts, } \\
\text { extracts, adds, } \\
\text { suggesting, } \\
\text { published }\end{array}$ \\
\hline Total & 120 & 11 & 23 & 6 \\
\hline
\end{tabular}

Out of 120 look-ups, 11 (9.1\%) were misidentified for their word class. The subjects might not have been aware that one word form could have more than one word class. For example, 'research' can function as a verb and also a noun. The subjects might not have analyzed the part of speech where the word 'research' occurred in context. A second reason for this unidentified word class would have been because of the PEDs the subjects used.

Locating inappropriate words to look up is a major problem for dictionary consultation. It is seen that out of 120, 23 words (19.2\%) were inappropriately chosen to look up. It seems that the subjects copied the exact word form from the article to look up in their PEDs, without analyzing the part of speech or adjusting to remove inflections. For example, all 4 subjects looked up the word 'published' ('the Oxford-based research group Cochrane published a review of 51 studies') without adjusting this word to its root form ('publish'). Subject D selected the most number of inappropriate words to look up. These include: 'leaves', 'smokers', 'experts', 'extracts', 'adds', 'suggesting', 'conflicting', 'growing', 'published', 'included'. 
There are 6 look-ups that were unsuccessful. This was the result of failure in adjusting inflected forms appropriately. It should be noted that all of the unsuccessful look-ups were looked up by Subject D. This may at first be taken to imply that Subject D was the least skilful in PED use. However, after a careful investigation of the PED, it was found that the cause of these unsuccessful lookups could also have been the result of the PED brand the subject used. The investigation of the two PED brands (TalkingDict and CyberDict) revealed two important aspects: the content and the function.

It is interesting to note that the words 'conflicting' and 'growing' are listed as headwords in the TalkingDict (as adjectives). However, these two words did not exist as headwords in major English-English dictionaries (e.g. Longman Dictionary of Contemporary English on CD-ROM and Collins Cobuild Advanced Learner's Dictionary on CD-ROM).

The content of the English-Thai dictionary in CyberDict comes from Thiengburanathum's (1998) SE-ED's Modern English-Thai Dictionary (Complete and Updated) Desk Reference Edition, Bangkok: SE-Education. On the other hand, the content of the English-Thai dictionary in TalkingDict is taken from the English-Thai Dictionary (compiled by lecturers from the Chalermprakiat Centre of Translation and Interpretation). Note that no authors' titles or years of publication were provided.

CyberDict has a unique function that can display the most appropriate root form. For example, when typing 'suggests', 'suggesting', or 'suggested', the PED displays 'suggest'). This function, however, is not present in TalkingDict. Had Subject D used CyberDict to look up these six words, his searches would have been successful.

\section{Conclusion and Discussion}

The findings from the questionnaire survey suggest a growing trend for pocket electronic dictionaries. The findings accord with the findings of previous studies that PED use will increase (Taylor and Chan 1994, Midlane 2005). Only a few participants would like to buy monolingual dictionaries. This may be taken to imply that the use of monolingual dictionaries was imposed on the participants and if they had their own choice to choose what dictionaries to buy, they might not have bought monolingual dictionaries as recommended by the Department.

The findings from the 'Green tea' experiment revealed insights into how students use PEDs. The problems the subjects encountered revealed a lack of reading skills and dictionary-using skills. The subjects lacked strategies in tackling the reading task. Some did not perform any reading strategies, e.g. looking at the title, skimming, or reading the main ideas, guessing words from context. As a consequence, the lack of reading strategies had led the subjects to rely heavily on searching for equivalent meanings from the PEDs. The subjects' look-up behaviours, however, were found to be partial. Some subjects were not 
aware of the class word and inflected form of the words. Some of them did not select appropriate word forms to look up. However, the reason the subjects did not select the appropriate forms might have been the result of the difference between L1 (i.e. Thai) and L2 (i.e. English). For example, Thai does not have inflected forms (e.g. manage, manages, managed, managing) as in English. Thai derivational morphemes are prefixes rather than suffixes, e.g. จัดการ [chatkan] (verb 'manage'), การจัดการ [kanchatkan] (noun 'management') ผู้จัดการ [phuchatkan] (noun 'manager'). The subjects might not have been aware of this difference and this could affect dictionary use. Moreover, the PED brand was found to be an important factor hindering or promoting look-up success.

\section{Recommendation}

Since PEDs will continue appearing in the classroom, teachers should provide authoritative advice on how to buy PEDs and/or train students to use PEDs. Based on the findings of this research, the following guidelines for buying PEDs and for teaching PED skills are proposed: Teachers may ask students to explore and compare the dictionary contents of the PED the students would like to buy in terms of lexicographical features (e.g. name of dictionaries, their authors' titles, years of publication, and the edition of the specific dictionary), and technological features (e.g. an ability to display the root form, wild card search). Teachers may teach students to make sure that they know how to identify the part of speech of words, how to adjust inflected forms to find root forms, and how to analyze word classes. When teaching English to a multilingual class, it is useful for teachers to teach fundamental facts about the L1 and the L2 (i.e. English), so that they know how differences can affect the way they will use their PEDs.

\section{References}

Atkins, B.T.S. and K. Varantola. 1998. Monitoring Dictionary Use. Atkins, B.T.S. (Ed.). 1998. Using Dictionaries. Studies of Dictionary Use by Language Learners and Translators: 83-122. Lexicographica. Series Maior 88. Tübingen: Max Niemeyer.

Boonmoh, A. and H. Nesi. 2008. A Survey of Dictionary Use by Thai University Staff and Students, with Special Reference to Pocket Electronic Dictionaries. Horizontes de Lingüística Aplicada 6(2): 79-90.

Deng, Y.P. 2005. A Survey of College Students' Skills and Strategies of Dictionary Use in English Learning. CELEA Journal 28(4): 73-77.

Jopling, F. 2003. Towards a New Methodology for Research on Electronic and Paper-Based Dictionary Use: A Pilot Study of Look-Up Patterns on Screen and in Print. Unpublished M.A. Thesis. Coventry: University of Warwick.

Koren, S. 1997. Quality versus Convenience: Comparison of Modern Dictionaries from the Researcher's, Teacher's and Learner's Points of View [online]. TESL-EJ 2(3), January. 
Midlane, V. 2005. Students' Use of Portable Electronic Dictionaries in the EFL/ESL Classroom: A Survey of Teacher Attitudes. M.Ed. Dissertation. Manchester: University of Manchester, Faculty of Education.

Nesi, H. and R. Haill. 2002. A Study of Dictionary Use by International Students at a British University. International Journal of Lexicography 15(4): 277-305.

Sobkowiak, W. 2002. The Challenge of Electronic Learner's Dictionaries [online]. Teaching English with Technology: A Journal for Teachers of English 2(1), January 2007. http://www.iatefl.org.pl/ call/j_article7.htm\#sob.

Tang, G. 1997. Pocket Electronic Dictionaries for Second Language Learning: Help or Hindrance? TESL Canada Journal 15(1): 39-57.

Taylor, A. and A. Chan. 1994. Pocket Electronic Dictionaries and their Use. Martin, W., W. Meijs, M. Moerland, E. ten Pas, P. van Sterkenburg and P. Vossen (Eds.). 1994. Euralex '94 Proceedings. Papers Submitted to the 6th EURALEX International Congress on Lexicography in Amsterdam, The Netherlands: 598-605. Amsterdam: Free University Press.

Tono, Y. 2000. On the Effects of Different Types of Electronic Dictionary Interfaces on L2 Learners' Reference Behaviour in Productive/Receptive Tasks. Heid, U., S. Evert, E. Lehmann and C. Rohrer (Eds.). 2000. Proceedings of the Ninth EURALEX International Congress, EURALEX 2000, Stuttgart, Germany, August 8th-12th, 2000: 855-862. Stuttgart: Institut für Maschinelle Sprachverarbeitung, Stuttgart University.

Weschler, R. and C. Pitts. 2000. An Experiment Using Electronic Dictionaries with EFL Students [online]. The Internet TESL Journal 6(8). http://iteslj.org/Articles/Weschler-ElectroDict.html.

Winkler, B. 2001. English Learners' Dictionaries on CD-ROM as Reference and Language Learning Tools. ReCall 13(2): 191-205. 
Appendix: Dictionary Use of Thai University Students

Please answer this questionnaire to find out more about your dictionary using habits. The information given will be kept confidential and answering this questionnaire will NOT affect your grades.

Please answer the following questions by ticking $(\checkmark)$ the appropriate spaces provided or answering in the spaces given.

(Personal information)

Faculty of study:

Major of study:

Email address:

Do you own/have any dictionaries?

$\square$ Yes (Please continue) $\square$ No (Please answer question 3)

(1) Which of these dictionaries do you have? You may tick more than one item.

(a) $\square$ Pocket electronic dictionary (e.g. TalkingDict, CyberDict, VTech)

Please specify which brand you have

(b) $\square$ Bilingual dictionary in book form

(c) $\square$ Monolingual dictionary in book form

Please specify which brand you have

(d) $\square$ Monolingual dictionary in $\mathrm{CD}$ form

(e) $\square$ Other(s)

Please specify

(2) Which dictionary do you prefer to use? Refer to the type of dictionary in question 1.

Type of dictionary

(3) If you do not have a dictionary or if you plan to buy a new dictionary, what type of dictionary would you like to buy? Refer to types of dictionaries in question 1.

Type of dictionary

Thank you for you cooperation. 